Bolm Inst. oceanogr., S Paulo, $31(2): 1-3,1982$

\title{
NOTES ON THE FEEDING OF BLENNIUS CRISTATUS LINNAEUS FROM A ROCKY POOL OF ITANHAÉM, SÃO PAULO STATE
}

\author{
Airton Santo TARARAM \& Yoko WAKABARA
}

Instituto Oceanogräfico da Universidade de São Paulo

\section{Synopsis}

This preliminary study analyzes the feeding habit of the fish Blennius cristatus inhabiting a rocky pool, in Itanhaém, south Zittoral of São Paulo State-Brazil. The main food items found were: Alga, Decapoda Reptantia, Mollusca and Amphipoda. The results showed that B. cristatus is an omnivorous species and probably also a trophic specialist preying on Gammaridea, but on Hyale media only, although twelve other species of the group were recorded in the sampling local.

\section{Introduction}

At the Itanhaem littoral region, tide pools with a rich crustacean fauna and some fish species are frequent, among the latter Blennius cristatus is the most abundant. Bohlke \& Chaplin (1970) recorded the species as an inhabitant of shallow rocky areas, tide pools and rocky slopes. Since no data on stomach contents of $B$. cristatus from Itanhaém have been published, the main purpose of this preliminary work is to provide information on its feeding habit.

\section{Study area}

The sampling site is a permanent saltwater pool according to Ganning's (1971) classification, and is located at Praia do Poço, It anhaém $\left(24^{\circ} 12^{\prime} \mathrm{S}\right.$ and $\left.46^{\circ} 47^{\prime} \mathrm{W}\right)$. During the sampling period (January and June, 1979), the average values of salinity, dissolved oxygen and water temperature were $31.53 \% \circ, 4.88 \mathrm{ml} / 1$ and $24.0^{\circ} \mathrm{C}$, respectively.

The pool is shallow, with a diameter of 5.0-6.0 m approximately, and some stones in it. Besides invertebrates, algae as Padina vickersiae and Sargassum stenophyllum are reasonably abundant, whereas Ulva sp and Enteromorpha sp are present in smaller quantity. Blennius cristatus is abundant and the presence of other fishes such as Paraclinus fasciatus, Labrisomus nuchipinnis, Mycteroperca rubra and Abudefduf sexatilis has also been noted.

Material and methods

Blennius cristatus was fished using hooks with shrimp baits and immediately preserved in $4 \%$ formalin. At the

Publ. n! 529 do Inst. oceanogr. da Usp. laboratory, the guts were removed, the contents examined under microscope, each food item was sorted and counted. The total volume of a food category was measured in a graduated measuring device, this displacement volume being equal to that of the food item. The data of the food analysis are expressed as percentage of occurrence and volume of all stomach contents.

\section{Results}

A11 the 40 stomachs of $B$. cristatus (Tab. I) contained food. The number of food items in each stomach varied from one to six and the mean number was three items. Excepting Alga (several species, not classified) and Mollusca (five species), almost all the food items were constituted by one or two species only.

The analysis of the stomach contents revealed the presence of seven items (Tab. I), as well as the occurrence of sand $(37.5 \%)$, mucus $(40.0 \%)$ and calcareous fragments $(10.0 \%)$. Considering the percentage of occurrence, Decapoda-Reptantia, Alga, Amphipoda, Mollusca, Polychaeta, Isopoda and Bryozoa is the order of importance of food items. However, if percentage volume is taken into account, this order should read Alga, DecapodaReptantia, Mollusca, Amphipoda, Isopoda, Polychaeta and Bryozoa.

Alga and Decapoda-Reptantia were ingested by most of the fishes (more than $50.0 \%$ ) and made up a considerable volume as well. On the other hand, Amphipoda, although found in more than $50.0 \%$ of the stomachs, presented a small volume, less than $10.0 \%$. Polychaeta was also a similar item, with high occurrence but with low volume. Mollusca 
Bolm Inst. oceanogr., S Paulo, 31(2), 1982

Table 1 - Stomach contents of 40 Blennius cristatus Linnaeus from Praia do Poço. ( ) = number of stomachs containing food i tems

\begin{tabular}{|c|c|c|c|}
\hline & Food item & $\begin{array}{c}\text { Occurrence } \\
(\xi)\end{array}$ & $\begin{array}{c}\text { Volume } \\
\text { (z) }\end{array}$ \\
\hline Á1ga (29) & 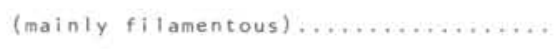 & 72.5 & 35.1 \\
\hline \multirow[t]{2}{*}{ Decapoda $(30)$} & Petrolisthes sp. $(02) \ldots \ldots \ldots \ldots \ldots$ & 5.0 & 3.1 \\
\hline & Fragments unidentified $(28) \ldots \ldots \ldots \ldots$ & 70.0 & 28.7 \\
\hline \multirow[t]{6}{*}{ Mollusca (16) } & Littorina ziczac (Gmelin) (02) ........ & 5.0 & 1.5 \\
\hline & Acmaea subrugosa orbigny $(04) \ldots \ldots \ldots$ & 10.0 & 2,5 \\
\hline & Modiolus carvalhoi Klappenback (02)... & 5.0 & 1.5 \\
\hline & Brachidontes sp. $(04) \ldots \ldots \ldots \ldots \ldots$ & 10.0 & 3.1 \\
\hline & Odostomia sp. $(01) \ldots \ldots \ldots \ldots \ldots \ldots$ & 2.5 & 1.5 \\
\hline & Juventles unidentified $(03) \ldots \ldots \ldots$ & 7.5 & 1.5 \\
\hline \multirow[t]{2}{*}{ Amphipoda (23) } & Hyale media (Dana) $(20) \ldots \ldots \ldots \ldots . . .$. & 50.0 & 6.3 \\
\hline & Fragments unidentified $(03) \ldots \ldots \ldots$ & 7.5 & 1.5 \\
\hline \multirow[t]{2}{*}{ Isopoda $(06)$} & Sphacroma walkeri stebbing (05)....... & 12.5 & 4.7 \\
\hline & Dynoides castroi Loyola s Silva (01) & 2.5 & 1.5 \\
\hline \multirow[t]{2}{*}{ Polychaeta (15) } & Phragmatopoma lapidosa kinberg (03)... & 7.5 & 3.1 \\
\hline & Fragments probably Phragmatopoma (12). & 30.0 & 1.5 \\
\hline Bryozoa (02) & 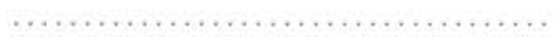 & 5.0 & 1.5 \\
\hline
\end{tabular}

in spite of its low occurrence, less than $50.0 \%$, constituted more than $10.0 \%$ of the stomach volume.

\section{Discussion}

Alga and Decapoda-Reptantia were the main food found in $B$. cristatus stomachs. It seems that species of Blennidae fed commonly on algae (Randa11, 1967; Gibson, 1972; Smith, 1974; Zander, 1980). According to Randa11 (1967), B. cristatus from West Indies showed $99.2 \%$ of algae and organic detritus in its stomachs. The amount of algae found in the stomachs of $B$. cristatus from Itanhaém and the presence of algae such as Padina, Sargassum, Ulva and Enteromorpha in the fish habitat, indicate that they constitute an important source of food, besides offering shelter and dispersal conditions. The bulk of fragments of large Decapoda-Reptantia and the low number of stomachs with entire animals may suggest they were dead when swallowed by $B$. cristatus. The crab Petrolisthes as food item was referred previously by Randall (op.cit.) only for carnivorous Blennidae, Labrisomus gupyi and $L$. nuchipinnis.

Mollusca contributed significantly to the somach volume, however the available organic material is probably not so large, because of its shell. They were referred by Randall (1967) as food for B. cristatus, L. gupyi and L. nuchipinnis. Smith (1974) pointed out eggs of molluscs as food item for $B$. cristatus.

The importance of Hyale media among the item Amphipoda is remarkable, constituting a valuable prey for the local fishes, at least for B. cristatus. Although as many as 13 species of Gammaridea have been recorded at the pool under observation (Tararam et al., 1981), only H. media was found with a high occurrence values in the stomach contents of the fish. Amphipoda were found previous $1 y$, in Blennidae Labrisomus nuchipinnis stomachs examined by Randall (1967), Lypophrys canevai and L. delmatinus analyzed by Zander (1980) and Blennius pholis studied by Gibson (1972).

At present, further investigations on a larger sampling and laboratory experiments are necessary, such as those carried out by Nelson (1979), to get a total view on the feeding of $B$. cristatus from Itanhaém. However, these preliminary results revealed that the fish ingested from abundant vagile preys such as easily captured phytal Gammaridea to other sessile and semisessile preys as Polychaeta and Mollusca. B. cristatus is an omnivorous species, feeding on algae and animals, and probably a trophic specialist, (Stoner \& Livingston, 1980) consuming 
certain species such as Hyale media in great quantity.

Resumo

0 presente estudo constitui-se numa anālise preliminar do häbito alimentar do peixe Blennius cristatus Linnaeus, comum nas poças da zona entre-marés do $1 i-$ toral de São Paulo.

As coletas foram realizadas na Praia

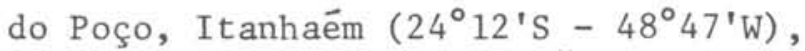
1itoral sul do Estado de São Paulo. A poça é rasa e mede $5,0-6,0 \mathrm{~m}$ de diâmetro, aproximadamente. 0 peixe foi capturado com anzol, usando-se, como isca, pedaços de camarão.

Os resultados mostraram que $B$. cristatus utilizou sete ítens alimentares:

Alga, Decapoda-Reptantia, Mollusca, Amphipoda, Isopoda, Polychaeta e Bryozoa. Além desses ítens, foram encontrados ainda nos estômagos examinados, areia, muco e fragmentos calcários. B. cristatus mostrou ser uma espécie omnívora, especializada em consumir Hyale media, apesar de, no local de coleta, ocorrerem muitas outras espécies de Gammaridea.

\section{Acknowledgements}

The authors wish to tank the following specialists for their help in the species identification: Dr. Y. Matsuura (Fishes), Dr. J. Abreu (DecapodaReptantia), Dr. A. M. S. Pires Vanin (Isopoda), M.Sc. P. C. Lana (Polychaeta), M.Sc. S. G. B. C. Lopes and T. M. Absher (Mollusca).

\section{References}

BOHLKE, J. E. \& CHAPLIN, C. C. G. 1970. Fishes of the Bahamas and adjacent tropical waters. Wynnewood, $\mathrm{Pa}$, Livingston, $771 \mathrm{p}$.

GANNING, B. 1971. Studies on chemical, physical and biological conditions in Swedish rockpool ecosystems. Ophelia, 9:51-105.
GIBSON, R. N. 1972. The vertical distribution and feeding relationships of intertidal fish on the Atlantic coast of France. J. Anim. Ecol., 41: 189-207.

NELSON, W. G. 1979. An analysis of structural pattern in an eelgrass (Zostera marina L.) amphipod community. J. Exp. mar. Biol. Ecol., 39: 231-264.

RANDALL, J. E. 1967. Food habits of reef fishes of the West Indies. Stud. trop. Oceanogr., 5:665-847.

SMITH, R. L. 1974. On the biology of Blennius cristatus with special reference to anal fin morphology. Bu11. mar. Sci., 24(3):595-605.

STONER, A. W. \& LIVINGSTON, R. J. 1980. Distributional ecology and food habits of the banded blenny Paraclinus fasciatus (Clinidae): a resident in a mobile habitat. Mar. Biol., 56:239246.

TARARAM, A. S.; WAKABARA, Y \& TAKEDA, A. M. 1981. Seasonal variations of Amphipoda species living on Sargassum in It anhaém, São Paulo - Brazil. II Sem. reg. de ecologia. São Carlos, Universidade Federal de São Carlos, p. 305-321.

ZANDER, C. D. 1980. Morphological and ecological investigations on sympatric Lypophrys species (Blennidae, Pisces). Helgoländer wiss. Meeresunters., $34: 91-110$.

(Manuscript received on 15/Jun./1982; accepted on 13/Aug./1982) 